\title{
Article \\ Optimization of Microbial Hydrolysis Parameters of Poultry By-Products Using Probiotic Microorganisms to Obtain Protein Hydrolysates
}

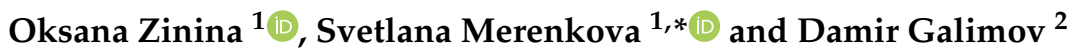 \\ 1 Department of Food and Biotechnology, South Ural State University (National Research University), \\ 76 Lenin Avenue, 454080 Chelyabinsk, Russia; zininaov@susu.ru \\ 2 Scientific and Educational Center of Nanotechnology, South Ural State University (National Research \\ University), 76 Lenin Avenue, 454080 Chelyabinsk, Russia; galimovdm@susu.ru \\ * Correspondence: merenkovasp@susu.ru
}

Citation: Zinina, O.; Merenkova, S.; Galimov, D. Optimization of Microbial Hydrolysis Parameters of Poultry By-Products Using Probiotic Microorganisms to Obtain Protein Hydrolysates. Fermentation 2021, 7, 122. https://doi.org/10.3390/ fermentation7030122

Academic Editor: Nhuan Nghiem

Received: 11 June 2021

Accepted: 18 July 2021

Published: 21 July 2021

Publisher's Note: MDPI stays neutral with regard to jurisdictional claims in published maps and institutional affiliations.

Copyright: (C) 2021 by the authors. Licensee MDPI, Basel, Switzerland. This article is an open access article distributed under the terms and conditions of the Creative Commons Attribution (CC BY) license (https:// creativecommons.org/licenses/by/ $4.0 /)$.

\begin{abstract}
In connection with the active growth of poultry processing, the issue of rational use of poultry by-products is urgent. The paper proposes hydrolysis of the gizzards of broiler chickens and hens of the parent stock with bifidobacteria liquid concentrate (BLC) and Propionix liquid concentrated starter culture (Propionix LCSC). The effect of enzymatic treatment on changes in the structural components of the gizzards was studied using scanning electron microscopy (SEM) and determination of the dispersed composition. As a result of the research, the multiple regression equations and the response surfaces were obtained, which describe the optimal parameters of the gizzard's hydrolysis process. The temperature and the time of hydrolysis are factors that have a significant effect on the degree of hydrolysis. The results of the structural and microscopic analysis confirm the high hydrolysability of the by-products by changing its structure and increasing the number of smaller protein particles. It was found experimentally that the gizzards of hens are more susceptible to the action of probiotic microorganisms' enzymes compared to the gizzards of broiler chickens.
\end{abstract}

Keywords: by-product; fermentation; propionic acid bacteria; bifidobacteria; parent stock; broiler chicken; gizzard

\section{Introduction}

All over the world, industrial poultry farming is developing rapidly from year to year [1]. Complexes of various capacities equipped with modern technological lines appear in different countries, new technologies for processing poultry are being introduced, and highly productive crosses are being bred. Poultry products are now the most important source of animal protein in many countries around the world, and this trend underscores the importance of the poultry processing industry and is driving its continued growth [2]. Today, for many poultry processing enterprises, the problem of rational use of agricultural poultry by-products, rich in proteins, is relevant [3]. Heads, legs, ridges, and gizzards are by-products formed during the primary processing of poultry and are of limited use in modern food production [4]. The problem of processing by-products of the spent laying hens and parent stock, which are one potential source of proteins, is especially urgent [5]. Collagen, which is part of the by-product connective tissue, is a potential source of not only feed, but also of dietary protein [6]. Irrational or insufficient full use of proteincontaining raw materials is the reason for the existing environmental problems of the enterprises of the industry, as well as the lack of food resources [1,7,8]. Expanding the use of collagen-containing poultry by-products by modifying their properties in various ways is especially important given the active growth in the consumption of poultry meat and the development of poultry processing enterprises. 
Exposure to heat and acids leads to the denaturation of proteins and reduced functionality and biological value of nutrients [9]. The enzymatic treatment of the by-products is an economical and ecological alternative to traditional acid or alkaline modification of the raw material [8].

The potential of chicken by-products as substrates for the production of protein hydrolysates with various functional properties and biological activity has been noted by many researchers $[6,10,11]$. It is noted that proteins that are currently used as animal feed can be modified and improved for human consumption. They will make an important contribution to the future of human protein nutrition [9].

The process of protein hydrolysis is aimed at breaking the bonds between the amino acids that make up the protein in order to obtain a protein concentrate. These short-chain and low-molecular-weight protein components are able to be efficiently metabolized [12,13]. Bioactive peptides are formed during protein hydrolysis under the action of proteases synthesized by fermenting organisms [14]. Bioactive peptides, in addition to their nutritional value, have antimicrobial, antioxidant, and immunomodulatory activity, contributing to human health $[12,15]$. The global trend of maintaining a healthy lifestyle and eating highprotein foods for weight loss and weight control in order to optimize muscle function is contributing to the demand for short-chain protein concentrates [9].

Comparing various types of hydrolysis of by-products, it can be concluded that the enzymatic treatment is more physiological, which can be carried out both with the use of proteolytic enzymes and with the use of live bacteria cultures. Microbial fermentation occurs under the action of a set of enzymes produced by microorganisms. Extracellular proteins are hydrolyzed to peptides of various molecular weights and free amino acids (AAs) under the action of proteases. Small peptides can be metabolized by microbes to give free AAs $[13,14,16]$.

When choosing the hydrolysis method, the following criteria are taken into account: the ease of the extraction and isolation of proteins; proteins should preferably be in an undenatured state; the absence of concomitant compounds; a high solubility of the hydrolysate in a wide $\mathrm{pH}$ range; a complete amino acid profile [9].

The aim of the study is to optimize the parameters of the process of microbial hydrolysis of the gizzards of broiler chickens and parent stock hens to produce a protein concentrate product, and to analyze changes in the structure and properties of raw materials under the action of microbial enzymes.

\section{Materials and Methods}

\subsection{Raw Materials and Ingredients}

The stomach was obtained during the slaughter of broiler chickens at the age of 41 days (ROSS-308), and hens of parent stock at the age of 11 months (average weight $4 \mathrm{~kg}$ ). The muscular stomach (gizzard) was separated from the glandular stomach, washed, packaged in plastic bags, and frozen at $-18{ }^{\circ} \mathrm{C}$. Frozen gizzards were transported in a refrigerator to the laboratory of the Food and Biotechnology Department within $2 \mathrm{~h}$ for further processing.

The whey was collected after the production of soft cheese and used with bacterial concentrates for the treatment of the gizzards. The proximate composition of the whey (\%): moisture content-93.12; protein content-0.96; fat content-0.37; ash content-0.61.

Bifidobacteria liquid concentrate (BLC) and Propionix liquid concentrated starter culture (Propionix LCSC), produced by Propionix company (Moscow, Russia), were used for bioconversion of the gizzards. BLC is a concentrated microbial mass of the Bifidobacterium longum B379M strain with an activity of $10^{11}-10^{12} \mathrm{CFU} / \mathrm{cm}^{3}$. Propionix LCSC is a concentrated microbial mass of the Propionibacterium freudenreichii subsp strain. shermanii-KM 186, the bacteria of which are in the active form $10^{10}-10^{11} \mathrm{CFU} / \mathrm{cm}^{3}$. 


\subsection{Biotechnological Treatment of the Gizzards}

Gizzards were thawed, ground in a meat grinder (Fimar 32/RS Unger, Rimini, Italy) and then in a grinder (Binatone, MFP 076). Gizzards were defatted three times with a mixture of chloroform: methanol (2:1), shaking for $2 \mathrm{~h}$ (Folsh and Stenly, 1957). Presterilized whey was added to the defatted mass in a ratio of 1:8 and homogenized (Stegler DG-360, Guangzhou, China), then liquid bacterial concentrates in the amount of 5, 10, and $15 \%$ to the gizzards weight were added to the gizzards mass and thoroughly mixed. Gizzards homogenates without the addition of bacterial concentrates were taken as a control sample. The homogenates were kept in a thermostat for $12 \mathrm{~h}$ at temperatures of 30, 35 , and $40{ }^{\circ} \mathrm{C}$.

\subsection{Optimization of Hydrolysis}

A multifactorial experiment was used to determine the optimal conditions for the hydrolysis process. Three factors were varied in the experiment: amount of bacterial concentrate $(5-15 \%)$ in $5 \%$ steps, temperature $\left(30-40{ }^{\circ} \mathrm{C}\right)$ in $5{ }^{\circ} \mathrm{C}$ steps, and hydrolysis time (4-12 h) in $4 \mathrm{~h}$ steps. The dependent variable was the degree of hydrolysis $(\mathrm{DH}, \%)$, which was calculated by the formula:

$$
D H=\left(\frac{N_{A A}-N_{A A 0}}{N_{O A}-N_{A A 0}}\right) \times 100 \%
$$

where $N_{O A}$ is the content of total nitrogen, $\% ; N_{A A 0}$ is the amine nitrogen in the nonhydrolyzed gizzards, $\% ; N_{A A}$ is the the content of amine nitrogen in the hydrolysate after hydrolysis for a certain period of time, $\%$.

The content of total nitrogen, amine nitrogen in the non-hydrolyzed gizzards, and the resulting hydrolysates was determined by the biuret method.

Effect of independent variables on the dependent variable $(D H)$ was analyzed using MathCAD (PTC: order \#2456861 \#2497812). When constructing the multiple regression equation, the following indicators were determined: the regression coefficients, the reliability of the equation by the coefficient of determination $\left(R_{2}\right)$ and the Fisher criterion $(\mathrm{Fkr})$, and the statistical significance of the parameters of the multiple regression equation by the Student's criterion $(t)$. The partial correlation coefficient $(\beta)$ was calculated in order to assess the validity of the inclusion of independent variables in the regression model.

In general, the equation for a three-factor experiment looks like this:

$$
\begin{gathered}
\mathrm{Y}=\mathrm{b}_{0}+\mathrm{b}_{1} \mathrm{X}_{1}+\mathrm{b}_{2} \mathrm{X}_{2}+\mathrm{b}_{3} \mathrm{X}_{3}+\mathrm{b}_{12} \mathrm{X}_{1} \mathrm{X}_{2}+\mathrm{b}_{13} \mathrm{X}_{1} \mathrm{X}_{3}+\mathrm{b}_{23} \mathrm{X}_{2} \mathrm{X}_{3}+\mathrm{b}_{123} \mathrm{X}_{1} \mathrm{X}_{2} \mathrm{X}_{3} \\
+\mathrm{b}_{11} \mathrm{X}_{1}^{2}+\mathrm{b}_{22} \mathrm{X}_{2}^{2}+\mathrm{b}_{33} \mathrm{X}_{3}^{2}
\end{gathered}
$$

\subsection{Determination of Physical and Chemical Properties}

The determination of the chemical composition of gizzards was conducted in triplicate according to the methods described by AOAC (1995): total nitrogen content was assayed by the Kjeldahl method with nitrogen converted to equivalent protein content using a factor of 6.25 (Methods 992.15 and 992.23); moisture was determined according to method $950.46 \mathrm{~B}$; total fat was determined via the Soxhlet method (Methods $920.39 \mathrm{C}$ and 960.39). The ash content was determined via the dry ashing method (Method 920.153).

The active acidity in the hydrolysates was measured for 2 min using a portable $\mathrm{pH}-$ meter (HANNA HI83141). An electrode was inserted to a depth of $4 \pm 1 \mathrm{~cm}$.

The titrated acidity was analyzed in dynamics after $0,4,8$, and $12 \mathrm{~h}$ of fermentation by neutralizing the hydrolysate solution (in a ratio of $1: 5$ with water) with $0.1 \mathrm{~N} \mathrm{NaOH}$; the values were expressed in degrees of lactic acid.

\subsection{Determination of the Dispersed Composition}

The study of the dispersed composition and the analysis of the particle size in the hydrolysates was carried out using a laser diffraction analyzer Microtrac S3500. 


\subsection{Scanning Electron Microscopy (SEM)}

Changes in the microstructure of the gizzards hydrolysates during biotechnological processing were studied by scanning in a scanning electron microscope (SEM) JSM 7001F (JEOL, Tokyo, Japan). After freeze drying of the hydrolysates, $10 \times 5 \times 2 \mathrm{~mm}$ plates were cut from the briquettes and fixed on the aluminum plate of the sample holder using carbon adhesive tape. The surface of the samples was covered with a layer of electrically conductive material (gold) with a thickness of approximately $10 \mathrm{~nm}$. The gold-plated samples were imaged in the mode of registration of backscattered electrons at an accelerating voltage at the cathode of $20 \mathrm{kV}$.

\subsection{Statistical Analysis}

Analyses were performed in five replicates, each of which being measured three times. Results were expressed as the mean values of the five replicates \pm the standard deviation. Probability values of $p \leq 0.05$ were taken in order to indicate statistical significance. The data were analyzed via one-way ANOVA and the Tukey test using the free web-based software offered by Assaad et al. [17].

\section{Results and Discussion}

\subsection{Optimization of Hydrolysis}

When carrying out enzymatic hydrolysis of wastes, hydrolysates with a high degree of hydrolysis (DH) and yield are obtained [11,18]. The degree of hydrolysis (DH) characterizes the degree of enzymatic peptide cleavage of the protein substrate under the influence of various factors: hydrolysis time, reaction $\mathrm{pH}$, and enzyme concentration. According to Kurosawa et al. [19], the enzyme concentration, reaction temperature, and exposure period are important parameters that affect the efficiency of enzymatic hydrolysis.

The multiple regression equation and the response surface methodology were applied to determine the optimal values of the independent variables. Three factors were evaluated: the temperature $\left(\mathrm{X}_{1}\right)$, amount of bacterial concentrate $\left(\mathrm{X}_{2}\right)$, and hydrolysis time $\left(\mathrm{X}_{3}\right)$. The dependent variable was the degree of hydrolysis $(\mathrm{DH})$. This model proposed 17 experiments in total, including three replicas in the center point. A central composite rotatable design was used to determine the optimal process conditions for gizzards hydrolysis (Table 1).

Table 1. Central composite rotatable design matrix showing coded and actual values of process parameters and their effects on the response variable, degree of hydrolysis (DH).

\begin{tabular}{|c|c|c|c|c|c|c|c|}
\hline \multirow{2}{*}{ Run } & \multirow{2}{*}{$x_{1}$} & \multirow{2}{*}{$X_{2}$} & \multirow{2}{*}{$x_{3}$} & \multicolumn{2}{|c|}{ DH of Hen Gizzards } & \multicolumn{2}{|c|}{$\begin{array}{c}\text { DH of Broiler } \\
\text { Chicken Gizzards }\end{array}$} \\
\hline & & & & $\begin{array}{l}\text { Propionix } \\
\text { LCSC }\end{array}$ & BLC & $\begin{array}{l}\text { Propionix } \\
\text { LCSC }\end{array}$ & BLC \\
\hline 1 & $30(-1)$ & $5(-1)$ & $4(-1)$ & 10.3 & 15 & 6.1 & 4.5 \\
\hline 2 & $30(-1)$ & $15(+1)$ & $4(-1)$ & 12.9 & 8.5 & 15.4 & 12.4 \\
\hline 3 & $30(-1)$ & $5(-1)$ & $12(+1)$ & 51.3 & 54.8 & 28.5 & 15.2 \\
\hline 4 & $30(-1)$ & $15(+1)$ & $12(+1)$ & 46 & 46 & 52.4 & 29.2 \\
\hline 5 & $40(+1)$ & $5(-1)$ & $4(-1)$ & 18.7 & 23.9 & 16.9 & 16.9 \\
\hline 6 & $40(+1)$ & $15(+1)$ & $4(-1)$ & 15.8 & 20.3 & 27.2 & 21 \\
\hline 7 & $40(+1)$ & $5(-1)$ & $12(+1)$ & 53.7 & 57.9 & 46.7 & 44.1 \\
\hline 8 & $40(+1)$ & $15(+1)$ & $12(+1)$ & 64.6 & 62.1 & 57.8 & 52.2 \\
\hline 9 & $35(0)$ & $10(0)$ & $8(0)$ & 19.7 & 34.6 & 10.6 & 20.3 \\
\hline 10 & $35(0)$ & $10(0)$ & $8(0)$ & 18.1 & 33.5 & 12.5 & 21.9 \\
\hline 11 & $35(0)$ & $10(0)$ & $8(0)$ & 20.8 & 36.2 & 9.8 & 19 \\
\hline 12 & $48.6(1.2154)$ & $10(0)$ & $8(0)$ & 46.7 & 37.5 & 30.7 & 32.3 \\
\hline 13 & $23.5(-1.2154)$ & $10(0)$ & $8(0)$ & 19.5 & 20.3 & 12.3 & 9.8 \\
\hline
\end{tabular}


Table 1. Cont.

\begin{tabular}{cccccccc}
\hline \multirow{2}{*}{ Run } & \multirow{2}{*}{} & $\mathbf{X}_{\mathbf{1}}$ & $\mathbf{X}_{\mathbf{2}}$ & $\mathbf{X}_{\mathbf{3}}$ & \multicolumn{2}{c}{ DH of Hen Gizzards } & \multicolumn{2}{c}{$\begin{array}{c}\text { DH of Broiler } \\
\text { Chicken Gizzards }\end{array}$} \\
\cline { 5 - 8 } & & & & $\begin{array}{c}\text { Propionix } \\
\text { LCSC }\end{array}$ & $\mathbf{B L C}$ & $\begin{array}{c}\text { Propionix } \\
\text { LCSC }\end{array}$ & $\mathbf{B L C}$ \\
\hline 14 & $35(0)$ & $18.2(1.2154)$ & $8(0)$ & 29.1 & 35 & 39.2 & 25.8 \\
\hline 15 & $35(0)$ & $3.9(-1.2154)$ & $8(0)$ & 15.3 & 18.5 & 3.4 & 8.5 \\
\hline 16 & $35(0)$ & $10(0)$ & $14.6(1.2154)$ & 55.6 & 57.6 & 52.7 & 34.6 \\
\hline 17 & $35(0)$ & $10(0)$ & $3.1(-1.2154)$ & 15.1 & 17.8 & 9.1 & 6.2 \\
\hline
\end{tabular}

As a result of optimization, multiple regression equations were obtained for the hydrolysis process of the hen's gizzards by Propionix LCSC $\left(\mathrm{DH}_{1 \mathrm{~h}}\right)$ and BLC $\left(\mathrm{DH}_{2 \mathrm{~h}}\right)$ :

$$
\begin{array}{r}
\mathrm{DH}_{1 \mathrm{~h}}=31.6200+4.3572 \cdot \mathrm{X}_{1}+1.4715 \cdot \mathrm{X}_{2}+13.8082 \cdot \mathrm{X}_{3}+1.4467 \cdot \mathrm{X}_{1} \cdot \mathrm{X}_{2} \cdot \mathrm{X}_{3}+2.0904 \cdot \mathrm{X}_{3}{ }^{2} \\
\mathrm{DH}_{2 \mathrm{~h}}=33.9867+4.0536 \mathrm{X}_{1}+13.4315 \mathrm{X}_{3}+1.8383 \mathrm{X}_{3}{ }^{2}
\end{array}
$$

where $\mathrm{X}_{1}$ is the temperature $\left({ }^{\circ} \mathrm{C}\right), \mathrm{X}_{2}$ is the amount of bacterial concentrate $(\%)$, and $\mathrm{X}_{3}$ is the hydrolysis time (h).

The statistical significance of the equations has been proved by Fisher's criterion. It was found that the coefficient of determination was $87.82 \%$ for $\mathrm{DH}_{1 \mathrm{~h}}$ and $88.86 \%$ for $\mathrm{DH}_{2 \mathrm{~h}}$; therefore, approximately $90 \%$ of the total variability of $\mathrm{DH}_{1 \mathrm{~h}}$ and $\mathrm{DH}_{2 \mathrm{~h}}$ in the experiment is provided by changes in the $\mathrm{Xj}$ factors. Based on the maximum partial correlation coefficient, we conclude that the factor $\mathrm{X}_{3}$ has the most essential effect on the degree of hydrolysis. It was also noted that the model parameter-the amount of bacterial concentrate $\left(X_{2}\right)$-was statistically insignificant $(p \geq 0.1)$ for hen's gizzards hydrolyzing by BLC. When comparing the $p$-values within the independent variables, a high degree of reliability of the regression coefficients for the hydrolysis time $\left(X_{3}\right)(p \leq 0.0005)$ was noted (Table 2$)$.

Table 2. Results of statistical analysis of regression coefficients for independent variables $\left(X_{j}\right)$ during hydrolysis of hen gizzards.

\begin{tabular}{ccccccc}
\hline \multirow{2}{*}{ Variables } & \multicolumn{2}{c}{ Hydrolyzing by Propionix LCSC } & \multicolumn{3}{c}{ Hydrolyzing by BLC } \\
\cline { 2 - 7 } & $\begin{array}{c}\text { Regression } \\
\text { Coefficient } \\
\mathbf{( b )}\end{array}$ & $\begin{array}{c}\mathbf{t} \text { - } \\
\text { Student's } \\
\text { Criterion }\end{array}$ & $p$-Value & $\begin{array}{c}\text { Regression } \\
\text { Coefficient }\end{array}$ & $\begin{array}{c}\text { t- Student's } \\
\text { Criterion }\end{array}$ & $p$-Value \\
\hline Y-intersection & 31.6200 & 79.9449 & $p \leq 0.0005$ & 33.9867 & 85.9287 & $p \leq 0.0005$ \\
\hline Variable $\mathrm{X}_{1}$ & 4.3572 & 8.8432 & $p \leq 0.05$ & 4.0536 & 8.2270 & $p \leq 0.05$ \\
\hline Variable $\mathrm{X}_{2}$ & 1.4715 & 2.9864 & $p \leq 0.05$ & 0.3569 & 0.7244 & $p \geq 0.1$ \\
\hline Variable $\mathrm{X}_{3}$ & 13.8082 & 28.0244 & $p \leq 0.0005$ & 13.4315 & 27.2598 & $p \leq 0.0005$ \\
\hline Variable $\mathrm{X}_{1} \cdot \mathrm{X}_{2}$ & 0.7133 & 1.2372 & $p \geq 0.1$ & 1.0600 & 1.8384 & $p \geq 0.1$ \\
\hline Variable $\mathrm{X}_{1} \cdot \mathrm{X}_{3}$ & 0.6467 & 1.1215 & $p \geq 0.1$ & -0.1000 & -0.1734 & $p \geq 0.1$ \\
\hline Variable $\mathrm{X}_{2} \cdot \mathrm{X}_{3}$ & 0.3933 & 0.6821 & $p \geq 0.1$ & 0.3667 & 0.6359 & $p \geq 0.1$ \\
\hline Variable $\mathrm{X}_{1} \cdot \mathrm{X}_{2} \mathrm{X}_{3}$ & 1.4467 & 2.5091 & $p \leq 0.05$ & 0.6733 & 1.1678 & $p \geq 0.1$ \\
\hline Variable $\mathrm{X}_{1}{ }^{2}$ & 1.6472 & 2.1102 & $p \geq 0.1$ & 0.1050 & 0.1345 & $p \geq 0.1$ \\
\hline Variable $\mathrm{X}_{2}{ }^{2}$ & -0.4995 & -0.6399 & $p \geq 0.1$ & -0.3184 & -0.4079 & $p \geq 0.1$ \\
\hline Variable $\mathrm{X}_{3}{ }^{2}$ & 2.0904 & 2.6779 & $p \leq 0.05$ & 1.8383 & 2.3548 & $p \leq 0.05$ \\
\hline
\end{tabular}

At the 3D response levels, the dependent variable was fixed at the central level (Z-axis) and the influence of two independent variables on the response was fixed on the $Y$ and $X$ axes (Figure 1). According to the designed models of the response surface, the most optimal values of the factors were set as follows: for hen's gizzards hydrolyzing by Propionix LCSC: the temperature was $43.55^{\circ} \mathrm{C}$; the amount of bacterial concentrate was $12.62 \%$; the predicted degree of hydrolysis was $62.56 \%$ (Figure $1 \mathrm{~b}$ ). Within the studding parameters, an increase 


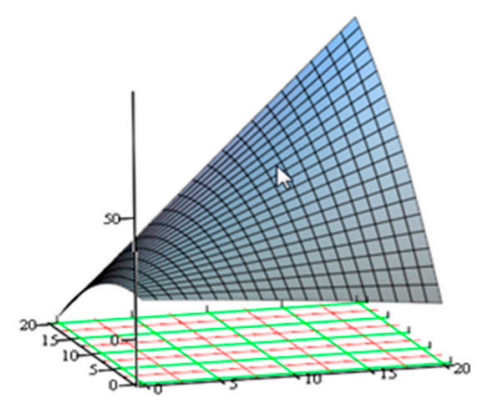

(a)

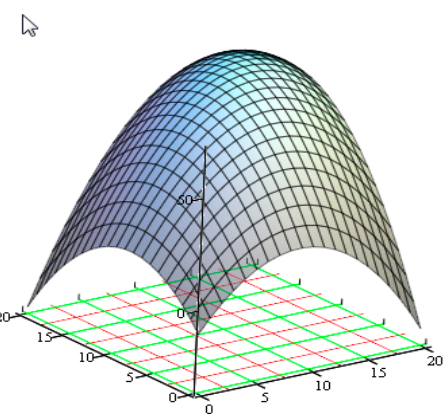

(d)

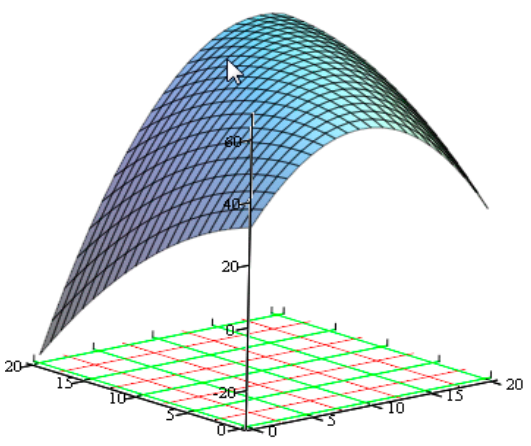

(b)

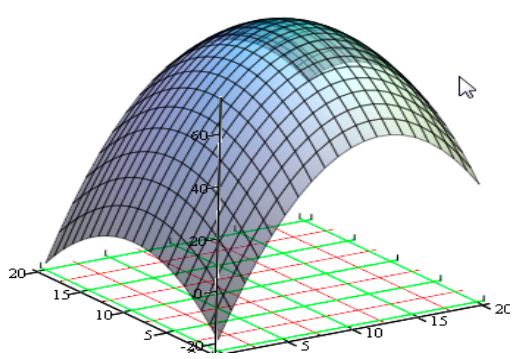

(e)

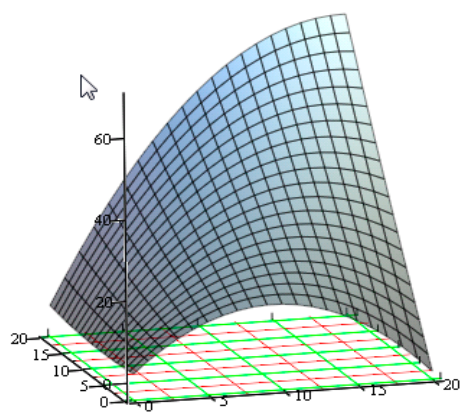

(c)

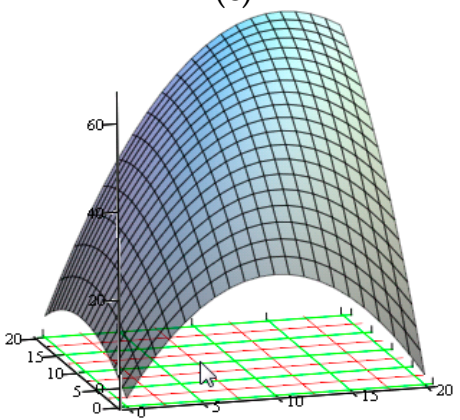

(f)

Figure 1. The 3D surface plots of degree of hen gizzards hydrolysis as a function of factors-when treated with Propionix LCSC: (a) interactions of temperature and time of hydrolysis on $\mathrm{DH}$; $(\mathbf{b})$ interactions of temperature and the amount of starter culture; (c) interaction of the amount of starter culture and hydrolysis time on DH; when treated with BLC: (d) interactions of temperature and time of hydrolysis on $\mathrm{DH}$; (e) interactions of temperature and the amount of starter culture; (f) interactions of the amount of starter culture and hydrolysis time on $\mathrm{DH}$. DH = degrees of hydrolysis.

The most optimal values of the factors for hen's gizzards hydrolyzing by BLC were set: the temperature was $40.68^{\circ} \mathrm{C}$; the hydrolysis time was $9.53 \mathrm{~h}$; the predicted degree of hydrolysis was $70.21 \%$ (Figure 1d). When plotting the response surfaces, the optimal concentration of the bacterial concentrate $(10.26 \%)$ and the fermentation temperature $\left(39.36{ }^{\circ} \mathrm{C}\right)$ were established, at which the degree of hydrolysis was $71.36 \%$ (Figure $2 b$ ). Moreover, with the recommended process parameters, an increase in the yield of hydrolyzed components was observed both with an increase in temperature (up to $39.36-40.68{ }^{\circ} \mathrm{C}$ ) and with an increase in the hydrolysis period (up to $9.5 \mathrm{~h}$ ). Increasing the amount of bacterial concentrate is effective up to a limit of $10.26 \%$.

As a result of optimization, multiple regression equations were obtained for the hydrolysis process of broiler chicken's gizzards by Propionix LCSC $\left(\mathrm{DH}_{1 \mathrm{bch}}\right)$ and BLC $\left(\mathrm{DH}_{2 \mathrm{bch}}\right)$ :

$$
\begin{aligned}
& \mathrm{DH}_{1 \mathrm{bch}}=27.2667+4.5709 \cdot \mathrm{X}_{1}+6.5408 \cdot \mathrm{X}_{2}+11.5194 \cdot \mathrm{X}_{3}+2.9066 \cdot \mathrm{X}_{3}{ }^{2} \\
& \mathrm{DH}_{2 \mathrm{bch}}=22.2000+6.6831 \cdot \mathrm{X}_{1}+3.6751 \cdot \mathrm{X}_{2}+8.0278 \cdot \mathrm{X}_{3}+2.0600 \cdot \mathrm{X}_{1} \cdot \mathrm{X}_{3}
\end{aligned}
$$

where $\mathrm{X}_{1}$ is the temperature $\left({ }^{\circ} \mathrm{C}\right), \mathrm{X}_{2}$ is the amount of bacterial concentrate $(\%)$, and $\mathrm{X}_{3}$ is the hydrolysis time $(\mathrm{h})$.

The statistical significance of the equations has been proved by Fisher's criterion. It was found that coefficient of determination is $83.58 \%$ for $\mathrm{DH}_{1 \mathrm{bch}}$ and $85.08 \%$ for $\mathrm{DH}_{2 \mathrm{bch}}$; therefore, more than $80 \%$ of the total variability of $\mathrm{DH}_{1 \mathrm{bch}}$ and $\mathrm{DH}_{2 \mathrm{bch}}$ in this experiment is provided by changes in the $\mathrm{X} j$ factors. Based on the maximum partial correlation coefficient, 
we conclude that the factor $X_{3}$ has the most essential effect on the degree of hydrolysis. It was also noted that the model parameters are statistically significant $(p \leq 0.05)$ (Table 3$)$.

Table 3. Results of statistical analysis of data for variables $\left(X_{j}\right)$ during hydrolysis of broiler chicken gizzards.

\begin{tabular}{ccccccc}
\hline & \multicolumn{2}{c}{ Hydrolyzing by Propionix LCSC } & \multicolumn{2}{c}{ Hydrolyzing by BLC } \\
\cline { 2 - 7 } Variables & $\begin{array}{c}\text { Regression } \\
\text { Coefficient } \\
(\mathbf{b})\end{array}$ & $\begin{array}{c}\text { t-Student's } \\
\text { Criterion }\end{array}$ & $p$-Value & $\begin{array}{c}\text { Regression } \\
\text { Coefficient } \\
\text { (b) }\end{array}$ & $\begin{array}{c}\text { t-Student's } \\
\text { Criterion }\end{array}$ & $p$-Value \\
\hline Y-intersection & 27.2667 & 63.1820 & $p \leq 0.0005$ & 22.2000 & 50.8516 & $p \leq 0.0005$ \\
\hline Variable $\mathrm{X}_{1}$ & 4.5709 & 8.5012 & $p \leq 0.05$ & 6.6831 & 12.2885 & $p \leq 0.001$ \\
\hline Variable $\mathrm{X}_{2}$ & 6.5408 & 12.1661 & $p \leq 0.001$ & 3.6751 & 6.7575 & $p \leq 0.05$ \\
\hline Variable $\mathrm{X}_{3}$ & 11.5194 & 21.4273 & $p \leq 0.0005$ & 8.0278 & 14.7611 & $p \leq 0.0005$ \\
\hline Variable $\mathrm{X}_{1} \cdot \mathrm{X}_{2}$ & -0.7866 & -1.2507 & $p \geq 0.1$ & -0.64667 & -1.0161 & $p \geq 0.1$ \\
\hline Variable $\mathrm{X}_{1} \cdot \mathrm{X}_{3}$ & 0.0666 & 0.1059 & $p \geq 0.1$ & 2.0600 & 3.2369 & $p \leq 0.05$ \\
\hline Variable $\mathrm{X}_{2} \cdot \mathrm{X}_{3}$ & 1.0267 & 1.6319 & $p \geq 0.1$ & 0.6733 & 1.0580 & $p \geq 0.1$ \\
\hline Variable $\mathrm{X}_{1} \cdot \mathrm{X}_{2} \cdot \mathrm{X}_{3}$ & -0.9200 & -1.4624 & $p \leq 0.05$ & -0.1400 & -0.2199 & $p \geq 0.1$ \\
\hline Variable $\mathrm{X}_{1}{ }^{2}$ & 1.0551 & 1.2387 & $p \geq 0.1$ & 0.9667 & 1.1219 & $p \geq 0.1$ \\
\hline Variable $\mathrm{X}_{2}{ }^{2}$ & 1.0157 & 1.1925 & $p \geq 0.1$ & 0.1985 & 0.2304 & $p \geq 0.1$ \\
\hline Variable $\mathrm{X}_{3}{ }^{2}$ & 2.9066 & 3.4125 & $p \leq 0.05$ & 0.8386 & 0.9733 & $p \geq 0.1$ \\
\hline
\end{tabular}

When comparing the $p$-values within the independent variables, a high degree of reliability for the regression coefficients was noted for the hydrolysis time $(p \leq 0.0005)$ $\left(\mathrm{X}_{3}\right)$, for the amount of bacterial concentrate $(p \leq 0.001)\left(\mathrm{DH}_{1 \mathrm{bch}}\right)$, and for the temperature $(p \leq 0.001)\left(\mathrm{DH}_{2 \mathrm{bch}}\right)$.

According to the designed models of the response surface, the most optimal values of the factors for broiler chicken's gizzards hydrolyzing by Propionix LCSC were set: the temperature was $39.92{ }^{\circ} \mathrm{C}$; the hydrolysis time was $9.4 \mathrm{~h}$; the predicted degree of hydrolysis was $64.49 \%$ (Figure $2 \mathrm{a}$ ); or, the amount of starter culture was $11.00 \%$; the temperature was $39.44{ }^{\circ} \mathrm{C}$; the degree of hydrolysis was $63.90 \%$ (Figure $2 \mathrm{~b}$ ). According to the applied methodology, we observe the correspondence of the most effective temperature and the degree of hydrolysis when comparing various reaction parameters.

The most optimal values of the factors for broiler chicken's gizzards hydrolyzing by BLC were set as follows: the temperature was $42.73{ }^{\circ} \mathrm{C}$; the amount of bacterial concentrate was $12.51 \%$; the predicted degree of hydrolysis was $49.22 \%$ (Figure $2 \mathrm{e}$ ); or, the amount of starter culture was $13.00 \%$; the hydrolysis time was $10.54 \mathrm{~h}$; the degree of hydrolysis was $56.43 \%$ (Figure 2f). 


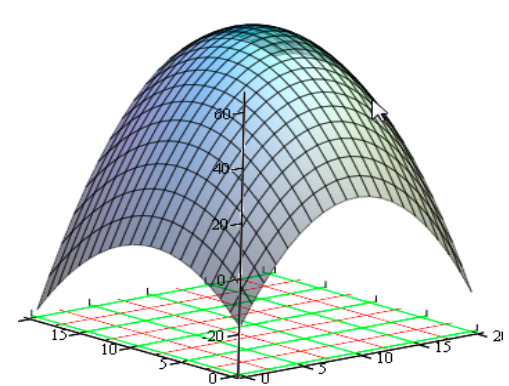

(a)

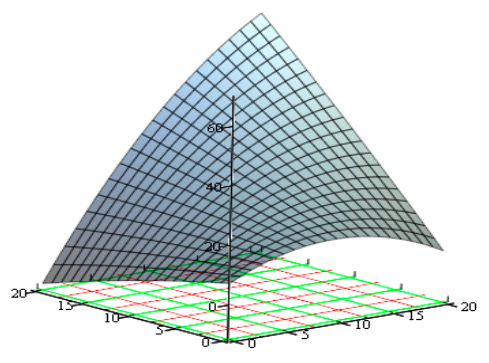

(d)

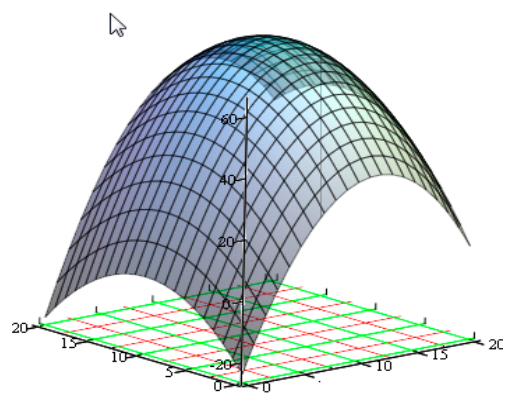

(b)

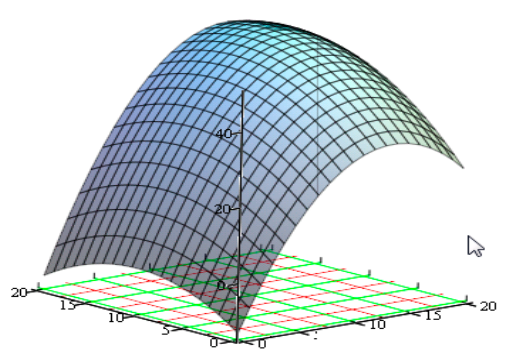

(e)

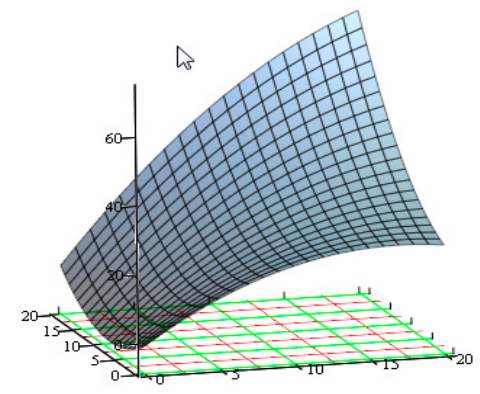

(c)

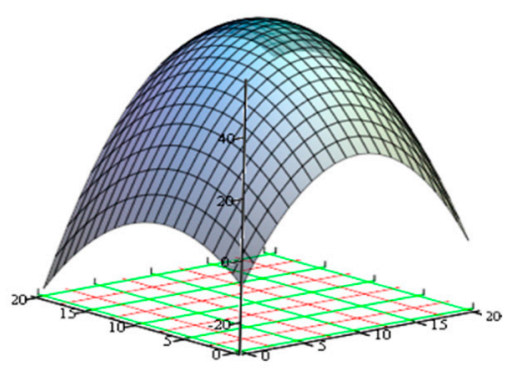

(f)

Figure 2. The 3D surface plots of degrees of broiler chicken gizzards hydrolysis as a function of factors-when treated with Propionix LCSC: (a) interactions of temperature and time of hydrolysis on $\mathrm{DH}$; $(\mathbf{b})$ interactions of temperature and the amount of starter culture; $(\mathbf{c})$ interactions of the amount of starter culture and hydrolysis time on DH; when treated with BLC: (d) interactions of temperature and time of hydrolysis on $\mathrm{DH} ;(\mathbf{e})$ interactions of temperature and the amount of starter culture; (f) interactions of the amount of starter culture and hydrolysis time on DH. DH = degrees of hydrolysis.

\subsection{Physical and Chemical Analyzes}

The proximate composition of gizzards is presented in Table 4.

Table 4. Proximate composition of gizzards.

\begin{tabular}{ccc}
\hline \multirow{2}{*}{ Indicator } & \multicolumn{2}{c}{ Value, $\%$} \\
\cline { 2 - 3 } & Hen Gizzard & Broiler Chicken Gizzard \\
\hline Moisture & $75.08 \pm 0.14^{\mathrm{a}}$ & $72.64 \pm 0.22^{\mathrm{b}}$ \\
\hline Protein & $17.88 \pm 0.06^{\mathrm{a}}$ & $20.70 \pm 0.08^{\mathrm{b}}$ \\
\hline Fat & $4.38 \pm 0.03^{\mathrm{a}}$ & $4.62 \pm 0.02^{\mathrm{a}}$ \\
\hline Ash & $1.76 \pm 0.01^{\mathrm{a}}$ & $1.81 \pm 0.01^{\mathrm{b}}$ \\
\hline
\end{tabular}

Values are means \pm SEM, $n=5$ per treatment group. Means in a column without a common superscript letter differ $(p<0.05)$ as analyzed by one-way ANOVA and the TUKEY test.

Zhumanova et al [20] detected the protein content of the chicken muscular stomach as $20 \mathrm{~g} / 100 \mathrm{~g}$, which agreed with our results. The proximate composition of raw gizzard determined by Arafa [21] is close to our results, and is the following (g/100 g): protein is 19.20 , fat is 2.01 , moisture is 76.77 , and ash is 1.21 . Our results are very different from the data obtained by Abdullah et al [22]: protein is 17.34, fat is 0.76 , moisture is 78.60 , and ash is 0.97 .

The proteolytic activity of endogenous and exogenous enzymes is a key process that affects the destructurization of meat proteins and, as a consequence, the accumulation of peptides and free amino acids. Changes in temperature and $\mathrm{pH}$ can affect the intensity of hydrolysis due to the variation in the activity of $\mathrm{pH}$ or thermo-sensitive enzymes [23,24].

The acidity of the food system is formed as a result of the accumulation of fermentation products; primarily lactic acid. The level of active and titrated acidity allows us to assess the intensity of the hydrolysis processes of poultry by-products. During the analysis of 
the acidity dynamics of the broiler chicken gizzards, a slight dependence on the type and concentration of starter culture was found, where temperature and hydrolysis time were the factors that most significantly affected this indicator (Figure 3).

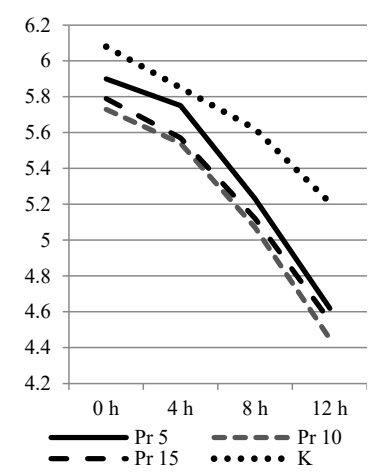

(a)

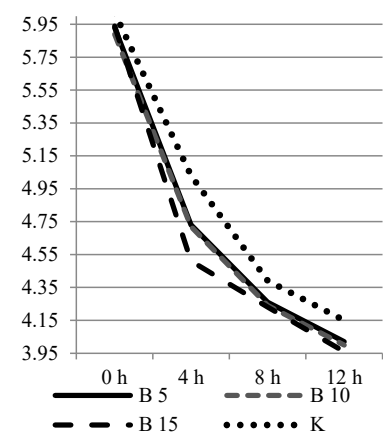

(e)

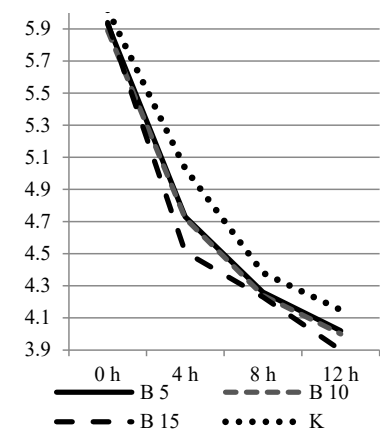

(i)

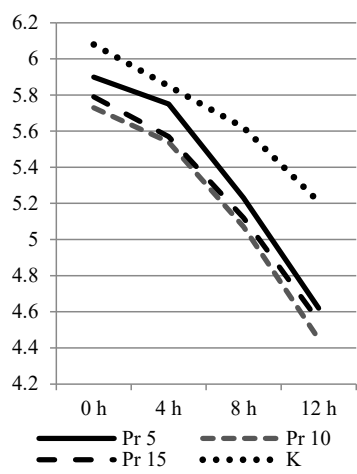

(b)

At temperature $30^{\circ} \mathrm{C}$

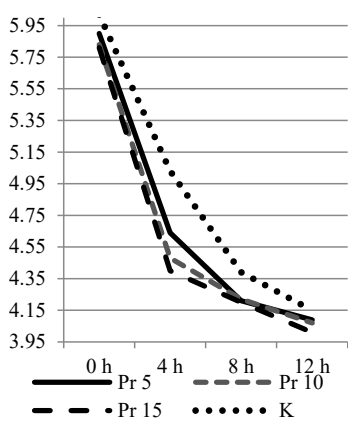

(f)

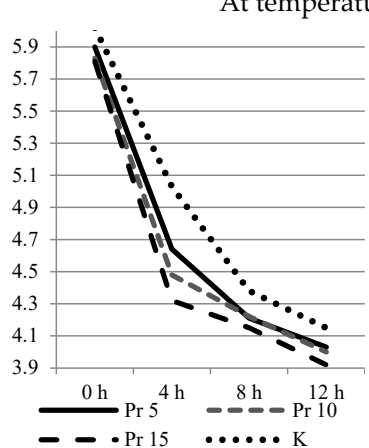

(j)

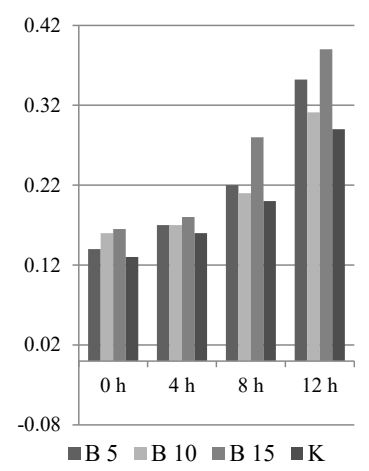

(c)

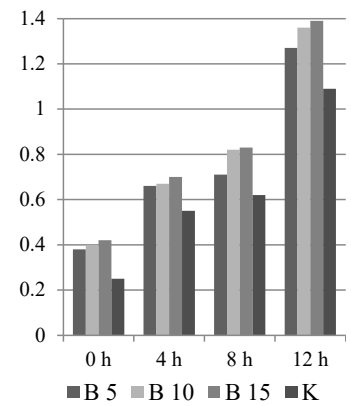

(g)

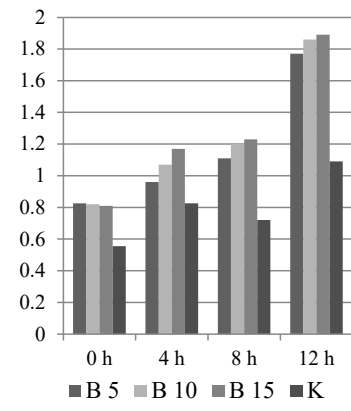

(k)

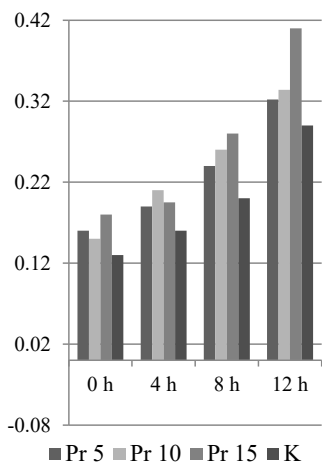

(d)

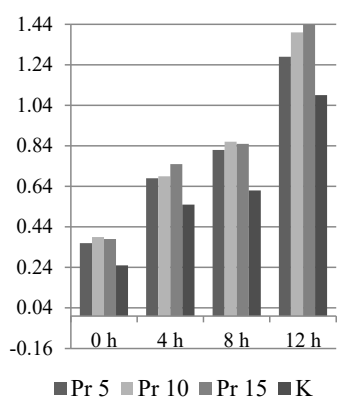

(h)

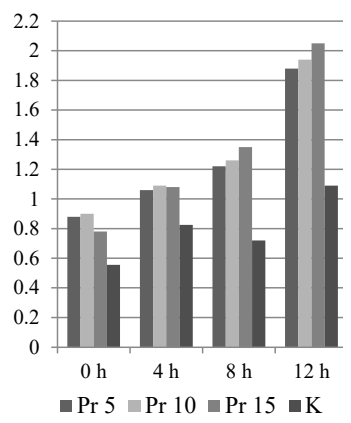

(1)

Figure 3. Dynamics of the acidity of broiler chicken gizzards during the hydrolysis period-at temperature $30{ }^{\circ} \mathrm{C}:(\mathbf{a}) \mathrm{pH}$ level, when treated with BLC; (b) pH level, when treated with Propionix LCSC; (c) titrated acidity, when treated with BLC; (d) titrated acidity, when treated with Propionix LCSC; at temperature $35^{\circ} \mathrm{C}$ : $(\mathbf{e}) \mathrm{pH}$ level, when treated with $\mathrm{BLC}$; (f) $\mathrm{pH}$ level, when treated with Propionix LCSC; $(\mathbf{g})$ titrated acidity, when treated with BLC; $(\mathbf{h})$ titrated acidity, when treated with Propionix LCSC; at temperature $40{ }^{\circ} \mathrm{C}$ : (i) $\mathrm{pH}$ level, when treated with BLC; (j) pH level, when treated with Propionix LCSC; (k) titrated acidity, when treated with BLC; (1) titrated acidity, when treated with Propionix LCSC.

After $12 \mathrm{~h}$ of fermentation, the active and titrated acidity of the samples treated with the bacterial concentrate reached values of 4.48-4.70 and 0.31-0.41 degrees of lactic acid at a temperature of $30^{\circ} \mathrm{C}, 3.96-4.09$ and 1.27-1.44 degrees at a temperature of $35^{\circ} \mathrm{C}$, and 3.90-4.03 and 1.77-2.05 degrees at a temperature of $40^{\circ} \mathrm{C}$, respectively, depending on the concentration of the starter culture.

Moreover, the hydrolysis processes proceeded more actively in the period of 4-12 h, at temperatures of $35^{\circ} \mathrm{C}$ and $40{ }^{\circ} \mathrm{C}$. Over this hydrolysis period, the active acidity decreased 
by $16.44-28.07 \%$ compared to the initial period $(0 \mathrm{~h})$ for control samples and decreased by $24.64-31.31 \%$ for samples fermented under the action of bifidobacteria and propionic acid bacteria. The obtained data are consistent with the results of the regression analysis of parameters for broiler chicken's gizzards hydrolysis, where the optimal conditions of the fermentation process were established: temperature was $39.9-42.7^{\circ} \mathrm{C}$ and hydrolysis period was 9.4-10.5 h.

The hydrolysis processes of the hen's gizzards proceeded more intensively in comparison with the fermentation of the broiler chicken gizzards. Thus, during the hydrolysis period of $12 \mathrm{~h}$, the active and titrated acidity reached values of 3.98-4.05 and 1.68-2.05 degrees of lactic acid at $35^{\circ} \mathrm{C}$, and 3.93-4.02 and 2.16-2.89 degrees of lactic acid at $40{ }^{\circ} \mathrm{C}$, respectively (Figure 4). Moreover, during the experiment, the most active fermentation was observed in the period of $4-12 \mathrm{~h}$ at a temperature of $40^{\circ} \mathrm{C}$, which correlates with the results of the optimization of hydrolysis processes of the hen's gizzards and the response surface models.

The authors noted that microbial proteases can interact with proteins in the fermented meat at a certain $\mathrm{pH}$ and temperature. Sun et al [25] detected that the protease secreted by Lactobacillus curvatus $\mathrm{R} 5$ are characterized by the following optimal fermentation conditions: a fermentation time of $36 \mathrm{~h}$, an initial $\mathrm{pH}$ of 6 , and a temperature of $37^{\circ} \mathrm{C}$. Protease from Lactobacillus fermentum R6 could exhibit a stable spatial structure at $\mathrm{pH} 7$ and $40{ }^{\circ} \mathrm{C}$, as established by Sun et al [26]. Li et al [27] in their study found the optimal conditions for pork trimmings transformations to protein hydrolysates with microbial protease Flavourzyme, which showed the highest degree of hydrolysis $48 \%$ at a temperature of $50{ }^{\circ} \mathrm{C}$, and a $\mathrm{pH}$ of 6 after $6 \mathrm{~h}$ of hydrolysis.

In order to achieve certain functional peptide properties, Thoresen et al [28] proposed specific technologies and operational conditions. The highest increase in the protein solubility was achieved at pH 6 and 11 as compared to pH 2 and 4. Enhanced solubility is associated with an increased degree of hydrolysis and accumulation of low molecular weight peptides, which increases the charges present per chain length at both acidic and alkaline conditions.

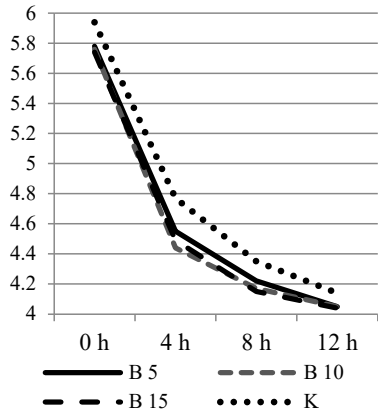

(a)

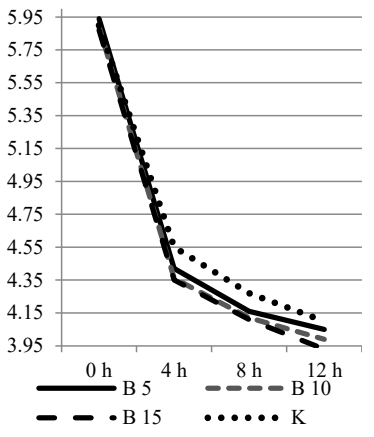

(e)

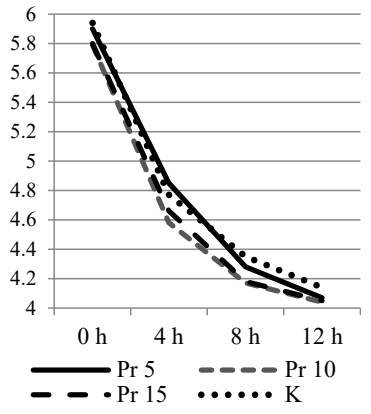

(b)

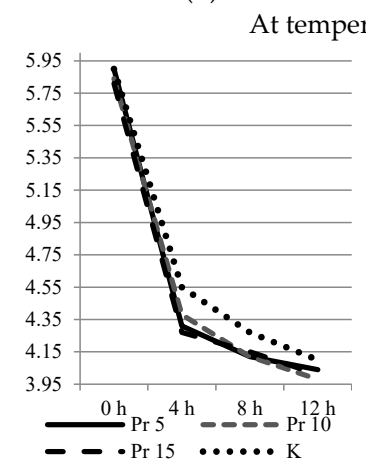

(f)

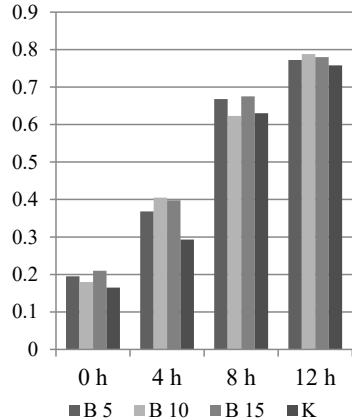

(c)

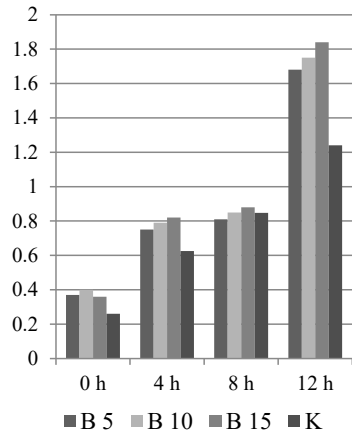

(g)

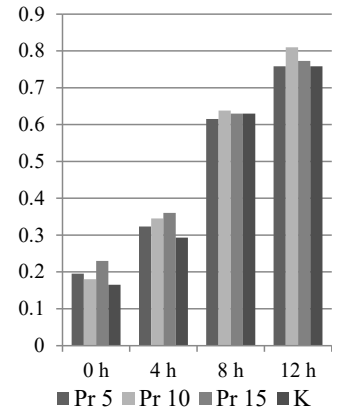

(d)

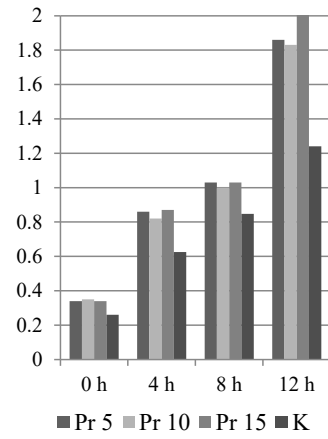

(h)

At temperature $35^{\circ} \mathrm{C}$

Figure 4. Cont. 


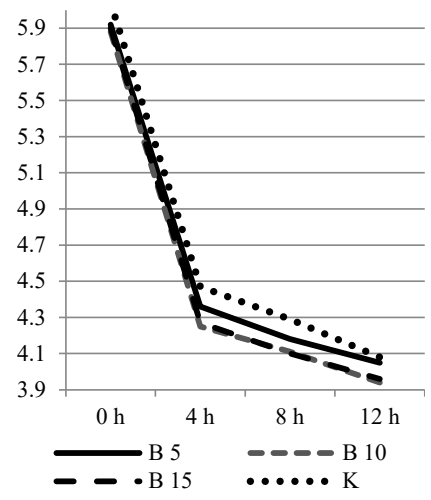

(i)

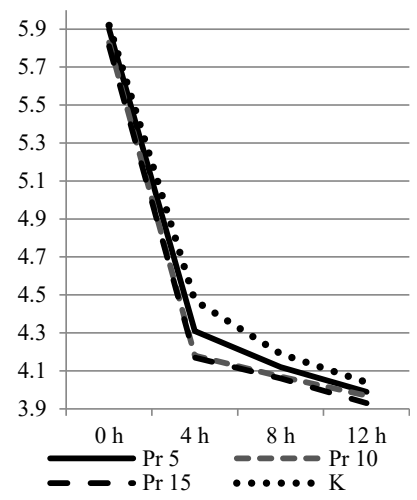

(j)

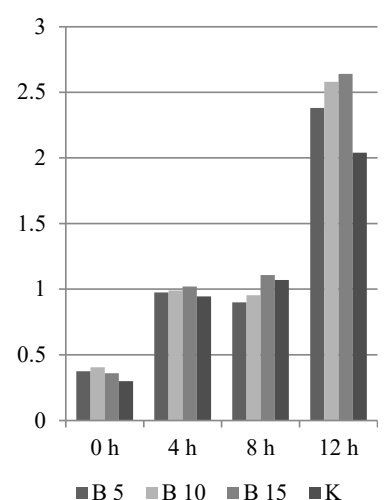

(k)

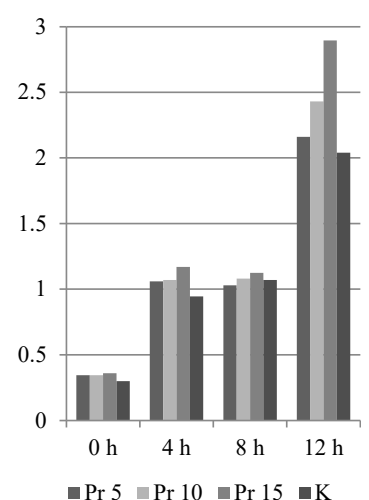

(1)

At temperature $40{ }^{\circ} \mathrm{C}$

Figure 4. Dynamics of the acidity of hen gizzards during the hydrolysis period-at temperature $30{ }^{\circ} \mathrm{C}:(\mathbf{a}) \mathrm{pH}$ level, when treated with BLC; (b) pH level, when treated with Propionix LCSC; (c) titrated acidity, when treated with BLC; (d) titrated acidity, when treated with Propionix LCSC; at temperature $35^{\circ} \mathrm{C}$ : (e) $\mathrm{pH}$ level, when treated with $\mathrm{BLC}$; (f) $\mathrm{pH}$ level, when treated with Propionix LCSC; $(\mathbf{g})$ titrated acidity, when treated with BLC; $(\mathbf{h})$ titrated acidity, when treated with Propionix LCSC; at temperature $40{ }^{\circ} \mathrm{C}$ : (i) $\mathrm{pH}$ level, when treated with BLC; (j) pH level, when treated with Propionix LCSC; (k) titrated acidity, when treated with BLC; (1) titrated acidity, when treated with Propionix LCSC.

\subsection{Dispersed Composition}

Studies of the dispersed composition of gizzards hydrolysates have shown that the particle size in samples treated with bacteria decreases (Figure 5). Thus, the average particle size in the dispersed system of hydrolysate of hens' gizzards decreased by almost 4 times, and decreased by almost 2 times in the hydrolysate of broiler chickens' gizzards (Table 5). The results of the evaluation of the dispersed composition prove that under the action of proteolytic enzymes produced by bacteria in the process of metabolism, proteins are broken down into simpler peptides. Hou et al [13] noted that the protein consists of one or more high molecular weight polypeptides that are degraded by enzymes on peptides of different molecular weights and free amino acids. The analysis of the measured hydrodynamic radii of various proteins, conducted by Wilkins et al [29], showed a correlation between the molecular size and the length of the polypeptide chain.

Table 5. Average hydrodynamic diameter determined from the numerical particle size distribution in hydrolysates.

\begin{tabular}{ccccc}
\hline Indicator & $\begin{array}{c}\text { Control Sample } \\
\text { in the Start Time }\end{array}$ & $\begin{array}{c}\text { Hydrolyzed Control } \\
\text { Sample }\end{array}$ & $\begin{array}{c}\text { Hydrolyzed Test Sample } \\
\text { with Propionix LCSC }\end{array}$ & $\begin{array}{c}\text { Hydrolyzed Test } \\
\text { Sample with BLC }\end{array}$ \\
\hline MN (MKM) & 11.83 & \multicolumn{2}{c}{ hens' gizzards } \\
\hline MN (MKM) & 11.29 & 6.60 & broiler chickens' gizzards & 2.73 \\
\hline
\end{tabular}




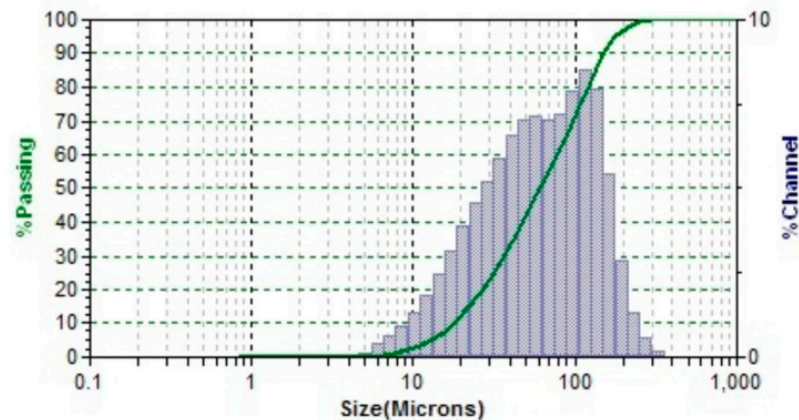

(a)

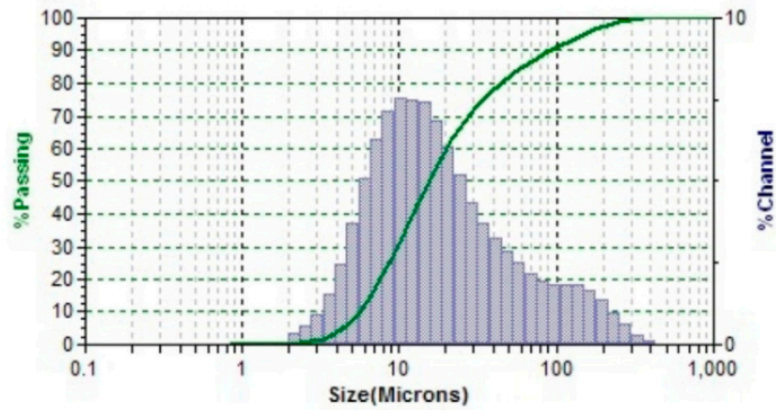

(c)

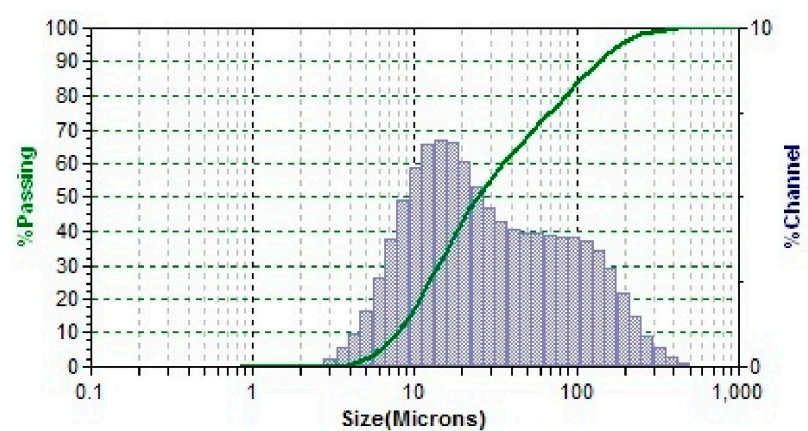

(b)

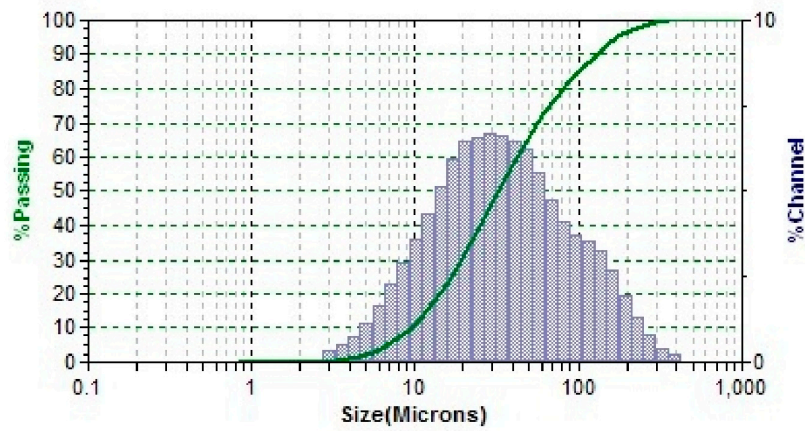

(d)

Samples of hen gizzards hydrolysates

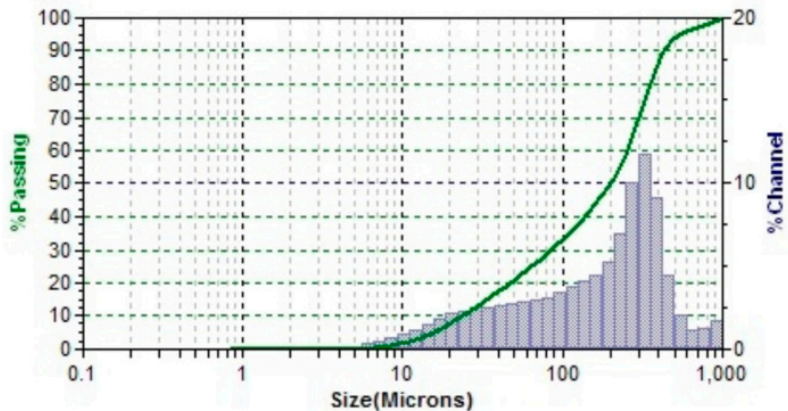

(e)

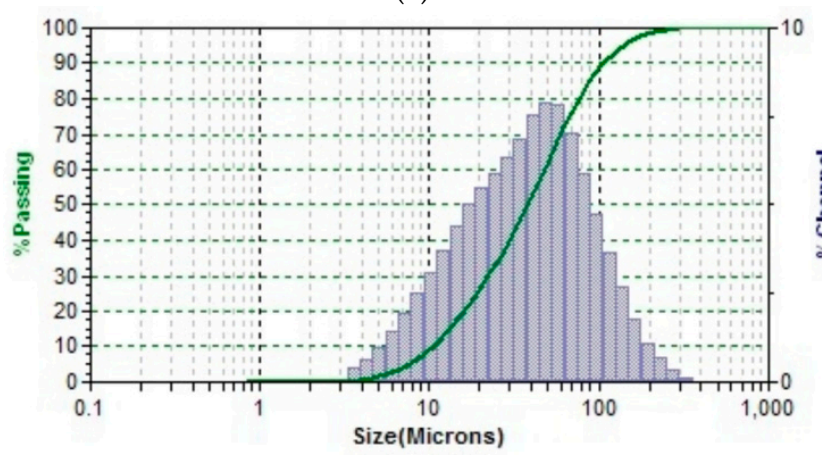

(g)

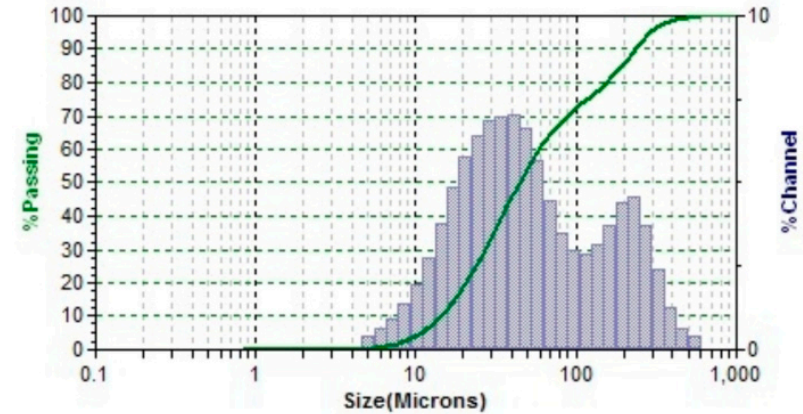

(f)

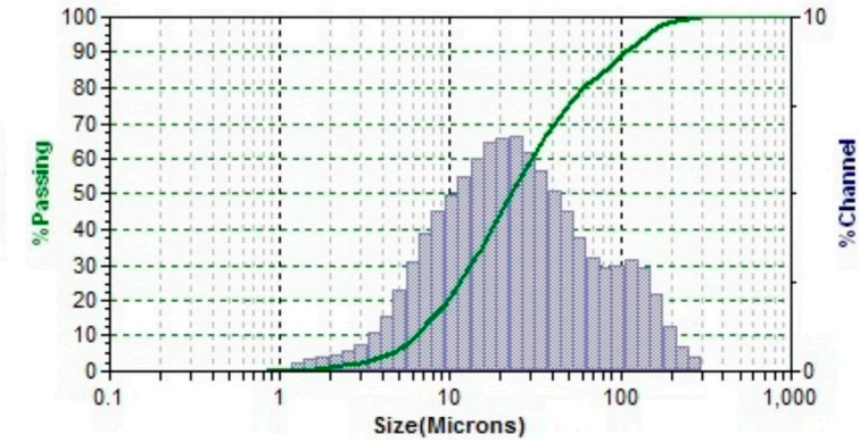

(h)

Samples of broiler chicken gizzards hydrolysates

Figure 5. The results of the evaluation of the dispersed composition of gizzards hydrolysates—samples of hen gizzards hydrolysates: (a) control sample in the start time; (b) hydrolyzed control sample; (c) hydrolyzed test sample with Propionix LCSC; (d) hydrolyzed test sample with BLC; samples of broiler chicken gizzards hydrolysates: (e) control sample in the start time; (f) hydrolyzed control sample; (g) hydrolyzed test sample with Propionix LCSC; (h) hydrolyzed test sample with BLC. 


\subsection{Scanning Electron Microscopy (SEM)}

The effect of various conditions of biotechnological processing on the microstructural properties of the gizzards samples was observed using SEM at different magnifications (Figures 6 and 7). The dried gizzards samples treated with bacterial concentrates (Figure 6(c1,d1) and Figure 7(c1,d1)) had a more open structure and greater porosity than the samples subjected to hydrolysis in whey without the addition of bacteria (Figure 6(b1) and Figure 7(b1)), as well as compared to the control sample (Figure 6(a1) and Figure 7(a1)). Chen et al. [30] noted a flake structure and a smooth surface in chicken liver protein hydrolysate obtained by treatment with trypsin. Microphotographs obtained with magnifications of 1000, 2000, and 5000 show a clear cleavage of muscle and collagen fibers in samples of gizzards treated with bacteria (Figures 6 and $7-\mathrm{A}$ ). In the control samples of gizzards, at the initial time, the matrix surface is more uniform and visually denser (Figure 6-B) and the collagen fibers have a multi-layered aggregated structure (Figure 6(a2)-C). A similar structure of collagen was observed by Akram and Zhang [31] when studying the microstructure of collagen extracted from chicken sternal cartilage. The destruction of structural components under the influence of ultrasound has been noted by several authors, which confirms a similar effect of exposure to the fibrillar proteins of a complex of proteolytic enzymes of bacteria [31-33]. Numerous thin fibrils, as well as thin films in the matrix cells, are observed in the gizzards of hens treated with bacteria (Figure 7(c4,d4)-D). After treating the gizzards with whey without the addition of bacteria, slight changes in fibers are observed in the microstructure, where there is less pronounced fiber dissociation (Figure 7(b2,b3)). The results of the study showed that under the action of bacteria, there is a significant change in the structure of collagen, its dissociation into numerous thin fibrils (Figure 6-D), and the formation of a reticular structure from them in combination with globular proteins and mineral components of whey (Figures 6 and 7-E, F).

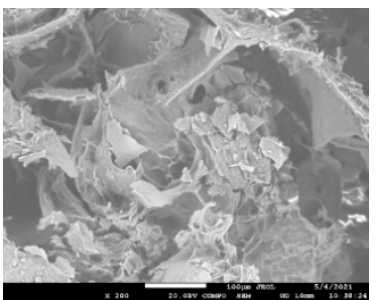

a1

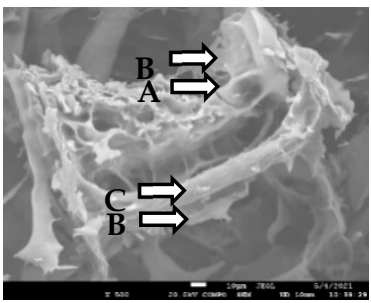

a2

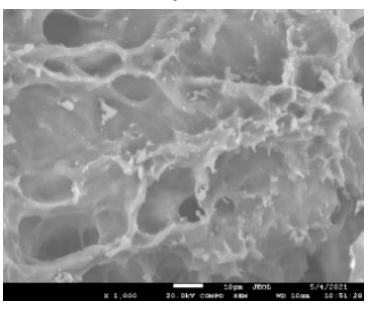

a3

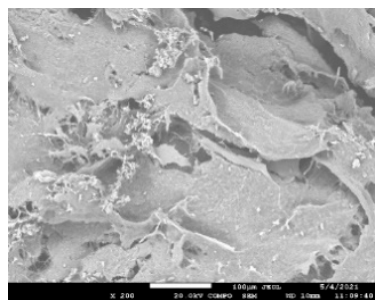

b1

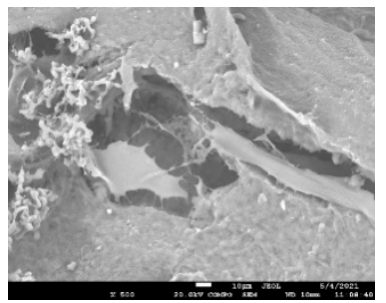

b2

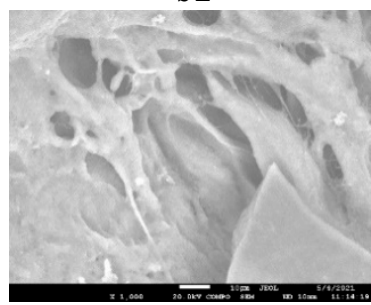

b3

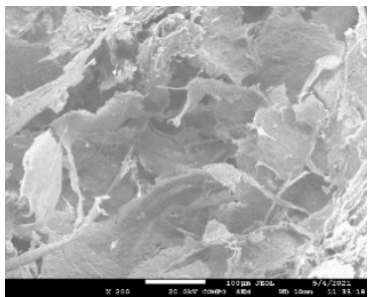

c1

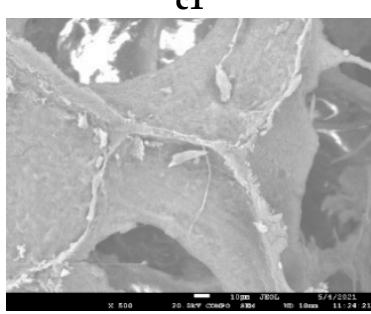

c2

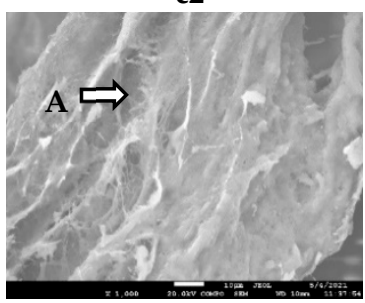

c3

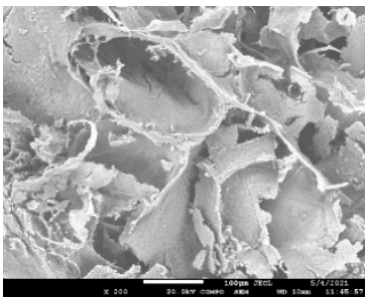

d1

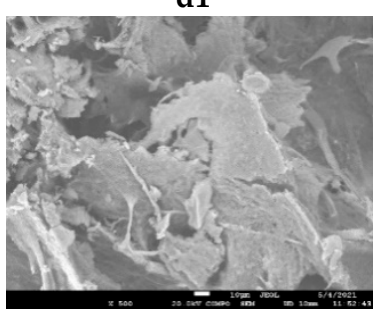

d2

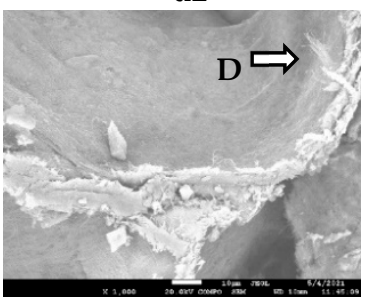

d3

Figure 6. Cont. 


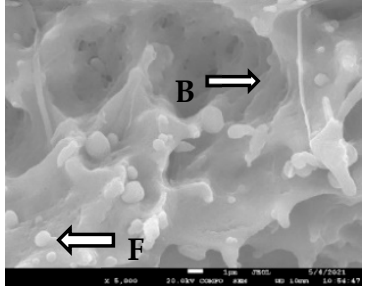

a4

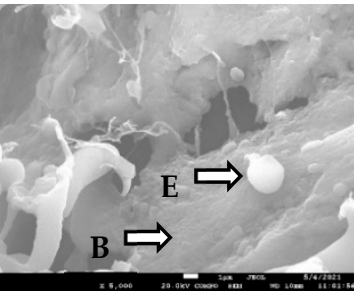

b4

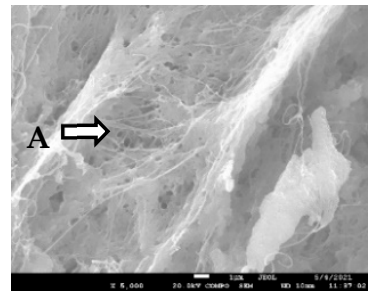

c4

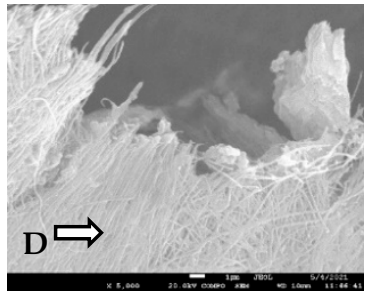

d4

Figure 6. SEM microscopic structure of broiler chicken gizzards hydrolysates: (a) control sample at the start of hydrolysis; (b) control sample at the end of hydrolysis; (c) hydrolyzed test sample with Propionix LCSC, (d) hydrolyzed test sample with BLC; A: fibrous structure of the matrix, B: uniform and dense matrix surface, D: thin fibrils, E: mineral components of whey, F: globular proteins; magnification: $(1) \times 200,(2) \times 500,(3) \times 1000,(4) \times 5000$.

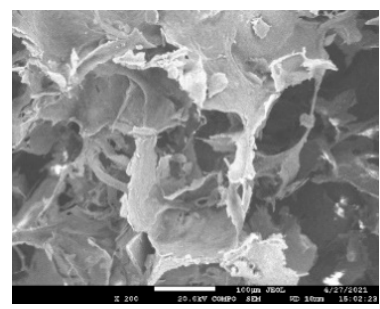

a1

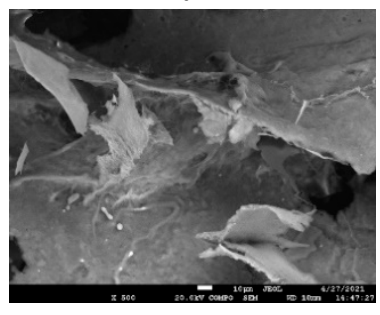

a2

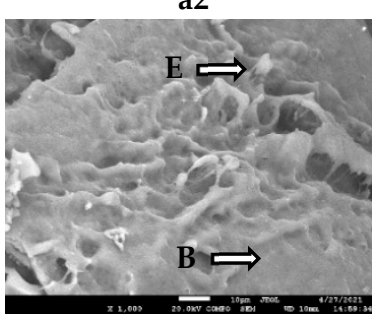

a3

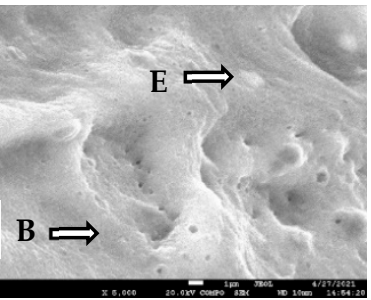

a4

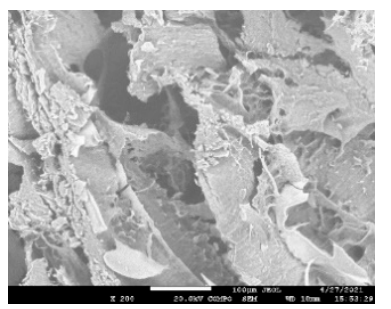

b1

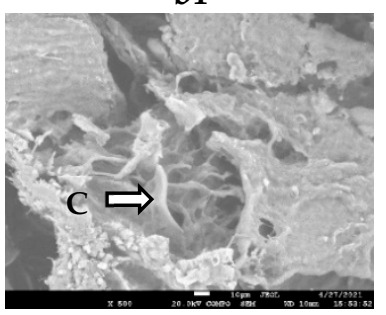

b2

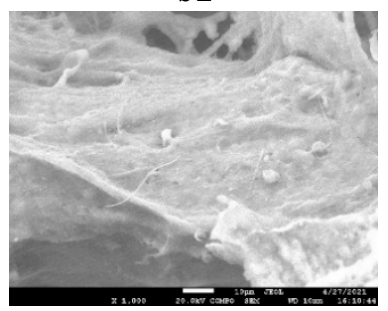

b3

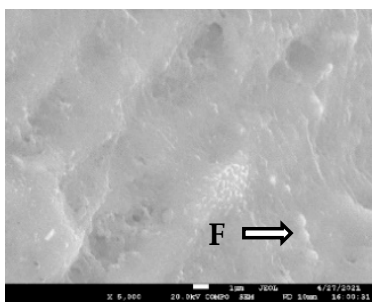

b4

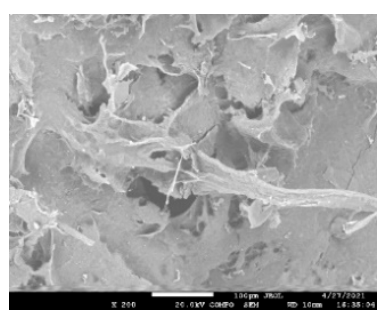

c1

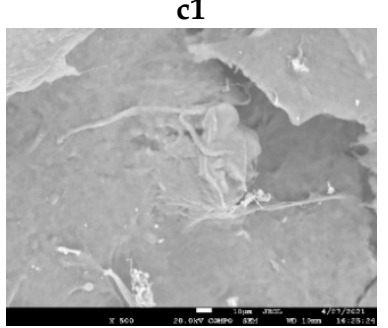

c2

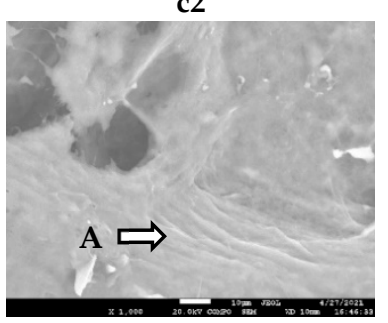

c3

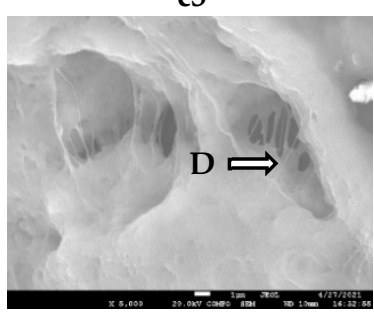

c4

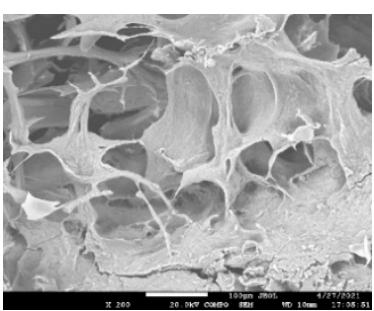

d1

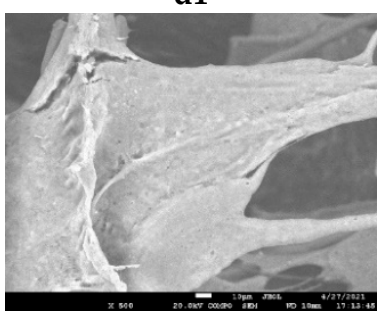

d2

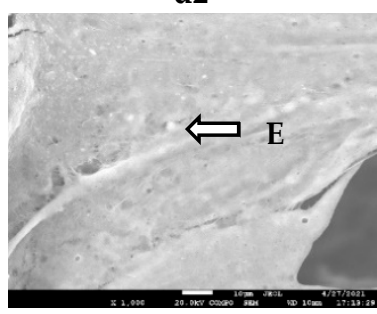

d3

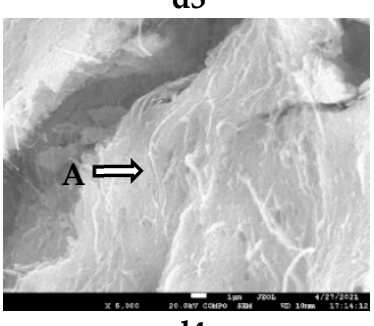

d4

Figure 7. SEM microscopic structure of hen gizzards hydrolysates: (a) control sample at the start of hydrolysis; (b) control sample at the end of hydrolysis; (c) hydrolyzed test sample with Propionix LCSC; (d) hydrolyzed test sample with BLC; A: fibrous structure of the matrix; B: uniform and dense matrix surface; C: aggregated collagen fiber; D: thin films; E: mineral components of whey; F: globular proteins; magnification: $(1) \times 200,(2) \times 500,(3) \times 1000,(4) \times 5000$.

\section{Conclusions}

The problem of rational use of poultry by-products is relevant for many poultry processing enterprises. The potential of chicken by-products for the production of protein hydrolysates with various functional properties and biological activity has been proven. 
The results of the study showed that biotechnological treatment of the broiler chickens and hen gizzards with concentrates of bifidobacteria and propionic acid bacteria has a positive effect on the degree of hydrolysis. As a result of the research, the multiple regression equations and the response surfaces were obtained, which describe the optimal parameters of the gizzard 's hydrolysis process. The temperature and the time of hydrolysis are factors that have a significant effect on the degree of hydrolysis. The results of the structural and microscopic analysis confirm the high hydrolysability of the by-products by changing its structure and increasing the number of smaller protein particles. It was found experimentally that the gizzards of hens are more susceptible to the action of probiotic microorganisms' enzymes compared to the gizzards of broiler chickens. This has been proven by the higher intensity of hydrolytic processes, the accumulation of fermentation products, and an increase in hydrolysate acidity, decrease in the particles size of the hydrolysis products, and morphological changes in microstructures.

Author Contributions: Conceptualization, O.Z.; methodology, O.Z. and S.M.; investigation, O.Z., S.M. and D.G.; data curation and analysis, O.Z. and S.M.; supervision, O.Z.; writing-original draft, O.Z. and S.M.; writing-review and editing, O.Z., S.M. and D.G. All authors have read and agreed to the published version of the manuscript.

Funding: The research was funded by RFBR and Chelyabinsk Region, project number 20-416-740002.

Data Availability Statement: Data will be made available up on request to the corresponding author.

Acknowledgments: We would like to thank managers of Scientific and Educational Center of Nanotechnology of South Ural State University for their technical support during this work.

Conflicts of Interest: The authors declare no conflict of interest. The funders had no role in the design of the study; in the collection, analyses, or interpretation of data; in the writing of the manuscript, or in the decision to publish the results.

\section{References}

1. Lasekan, A.; Bakar, F.A.; Hashim, D. Potential of chicken by-products as sources of useful biological resources. Waste Manag. 2013, 33, 552-565. [CrossRef] [PubMed]

2. Peña-Saldarriaga, L.M.; Fernández-López, J.; Pérez-Alvarez, J.A. Quality of chicken fat by-products: Lipid profile and colour properties. Foods 2020, 9, 1046. [CrossRef] [PubMed]

3. Roiter, L.M.; Zazykina, L.A.; Eremeeva, N.A. Poultry by-products, reserve for growth of export potential of the industry. IOP Conf. Ser. Earth Environ. Sci. 2019, 341, 012209. [CrossRef]

4. Zhu, G.; Zhu, X.; Wan, X.; Fan, Q.; Ma, Y.; Qian, J.; Liu, X.; Shen, Y.; Jiang, J. Hydrolysis technology and kinetics of poultry waste to produce amino acids in subcritical water. J. Anal. Appl. Pyrol. 2010, 88, 187-191. [CrossRef]

5. Zubair, M.; Wu, J.; Ullah, A. Hybrid Bionanocomposites from Spent Hen Proteins. American Chemical Society. ACS Omega 2019, 4, 3772-3781. [CrossRef]

6. Soares, M.; Rezende, P.C.; Corrêa, N.M.; Rocha, J.S.; Martins, M.A.; Andrade, T.C.; Fracalossi, D.M.; Vieira, F.N. Protein hydrolysates from poultry by-product and swine liver as an alternative dietary protein source for the Pacific white shrimp. Aquaculture Rep. 2020, 17, 100344. [CrossRef]

7. Alao, B.O.; Falowo, A.B.; Chulayo, A.; Muchenje, V. The potential of animal by-products in food systems: Production, prospect and challenges. Sustainability 2017, 9, 1089. [CrossRef]

8. Polaštíková, A.; Gál, R.; Mokrejš, P.; Orsavová, J. Preparation of protein products from collagen-rich poultry tissues. Potravin. Slovak J. Food Sci. 2020, 14, 713-720. [CrossRef]

9. Boland, M.J.; Rae, A.N.; Vereijken, J.M.; Meuwissen, M.P.M.; Fischer, A.R.H.; van Boekel, M.A.J.S.; Rutherfurd, S.M.; Gruppen, H.; Moughan, P.J.; Hendriks, W.H. The future supply of animal-derived protein for human consumption. Trends Food Sci. Technol. 2013, 29, 62-73. [CrossRef]

10. Rathina Raj, K.; Mahendrakar, N.S. Effect of ensiling and organic solvents treatment on proteolytic enzymes of layer chicken intestine. J. Food Sci. Technol. 2010, 47, 320-324. [CrossRef]

11. Santos, B.A.S.; Azambuja, S.P.H.; Ávila, P.F.; Pacheco, M.T.B.; Goldbeck, R. n-Butanol production by Saccharomyces cerevisiae from protein-rich agro-industrial by-products. Braz. J. Microbial. 2020, 51, 1655-1664. [CrossRef]

12. Saadi, S.; Saari, N.; Anwar, F.; Hamid, A.A.; Mohd-Ghazali, H. Recent advances in food biopeptides: Production, biological functionalities and therapeutic applications. Biotechnol. Adv. 2015, 33, 80-116. [CrossRef] [PubMed]

13. Hou, Y.; Wu, Z.; Dai, Z.; Wang, G.; Wu, G. Proteinhydrolysates in animal nutrition: Industrial production, bioactive peptides, and functional significance. J. Anim. Sci. Biotechnol. 2017, 8, 1-13. [CrossRef] [PubMed] 
14. Chai, K.F.; Hui Voo, A.Y.; Chen, W.N. Bioactive peptides from food fermentation: A comprehensive review of their sources, bioactivities, applications, and future development. Compr. Rev. Food Sci. Food Saf. 2020, 19, 3825-3885. [CrossRef] [PubMed]

15. García, C.A.; Manrique, I.M. Meat proteins as a potential source of bioactive ingredients for food and pharmaceutical use. In Novel Proteins for Food, Pharmaceuticals and Agriculture: Sources, Applications, and Advances; Hayes, M., Ed.; John Wiley \& Sons: Hoboken, NJ, USA, 2018; pp. 29-49. [CrossRef]

16. Smid, E.J.; Lacroix, C. Microbe-microbe interactions in mixed culture food fermentations. Curr. Opin. Biotechnol. 2013, 24, 148-154. [CrossRef] [PubMed]

17. Assaad, H.; Zhou, L.; Carroll, R.J.; Wu, G. Rapid publication-ready MS-Word tables 597 for one-way ANOVA. SpringerPlus 2014, 3, 474. [CrossRef] [PubMed]

18. Mirzaei Teshnizi, Z.; Robatjazi, S.M.; Mohammadian Mosaabadi, J. Optimization of the enzymatic hydrolysis of poultry slaughterhouse wastes using alcalase enzyme for the preparation of protein hydrolysates. Appl. Food Biotechnol. 2020, 7, 153-160. [CrossRef]

19. Kurozawa, L.; Park, K.; Hubinger, M. Optimization of the enzymatic hydrolysis of chicken meat using response surface methodology. J. Food Sci. 2008, 73, 405-512. [CrossRef]

20. Zhumanova, G.; Rebezov, M.; Assenova, B.; Okuskhanova, E. Prospects of using poultry by-products in the technology of chopped semi-finished products. Inter. J. Eng. Technol. 2018, 7, 495-498. [CrossRef]

21. Arafa, A.S. Pickled chicken gizzards: 1. Acceptability and proximate analysis. Inter. Poult. Sci. 1977, 56, 1014-1017. [CrossRef]

22. Abdullah, F.A.A.; Buchtova, H. Comparison of qualitative and quantitative properties of the wings, necks and offal of chicken broilers from organic and conventional production systems. Vet. Med. 2016, 61, 643-651. [CrossRef]

23. Lafarga, T.; Hayes, M. Bioactive peptides from meat muscle and by-products: Generation, functionality and application as functional ingredients. Meat Sci. 2014, 98, 227-239. [CrossRef] [PubMed]

24. Korhonen, H.; Pihlanto-Leppäla, A.; Rantamäki, P.; Tupasela, T. Impact of processing on bioactive proteins and peptides. Trends Food Sci. Technol. 1998, 9, 307-319. [CrossRef]

25. Sun, F.; Sun, Q.; Zhang, H.; Kong, B.; Xia, X. Purification and biochemical characteristics of the microbial extracellular protease from Lactobacillus curvatus isolated from Harbin dry sausages. Int. J. Biol. Macromol. 2019, 133, 987-997. [CrossRef]

26. Sun, F.; Tao, R.; Liu, Q.; Wang, H.; Kong, B. Effects of temperature and pH on the structure of a metalloprotease from Lactobacillus fermentum R6 isolated from Harbin dry sausages and molecular docking between protease and meat protein. J. Sci. Food Agric. 2021. [CrossRef]

27. Li, X.; Lee, P.R.; Taniasuri, F.; Liu, S.-Q. Biotransformation of pork trimmings into protein hydrolysate using microbial proteases aided by response surface methodology. J. Food Sci. Technol. 2021. [CrossRef]

28. Thoresen, P.P.; Alvarez, R.G.; Vaka, M.R.; Rustad, T.; Sone, I.; Fernandez, E.N. Potential of innovative pre-treatment technologies for the revalorisation of residual materials from the chicken industry through enzymatic hydrolysis Innovative. Food Sci. Emerg. Technol. 2020, 64, 102377. [CrossRef]

29. Wilkins, D.K.; Grimshaw, S.B.; Receveur, V.; Dobson, C.M.; Jones, J.A.; Smith, L.J. Hydrodynamic radii of native and denatured proteins measured by pulse field gradient NMR techniques. Biochemistry 1999, 38, 16424-16431. [CrossRef] [PubMed]

30. Chen, X.; Jiang, D.; Xu, P.; Geng, Z.; Xiong, G.; Zou, Y.; Wang, D.; Xu, W. Structural and antimicrobial properties of Maillard reaction products in chicken liver protein hydrolysate after sonication. Food Chem. 2021, 343, 128417. [CrossRef] [PubMed]

31. Akram, A.N.; Zhang, C. Extraction of collagen-II with pepsin and ultrasound treatment from chicken sternal cartilage; physicochemical and functional properties. Ultrason. Sonochem. 2020, 64, 105053. [CrossRef]

32. Aksoy, A.; Karasu, S.; Akcicek, A.; Kayacan, S. Effects of different drying methods on drying kinetics, microstructure, color, and the rehydration ratio of minced meat. Foods 2019, 8, 216. [CrossRef] [PubMed]

33. Krajewska, K.; Mierzwa, D. Influence of ultrasound on the microstructure of plant tissue. Innov. Food Sci. Emerg. Technol. 2017, 43, 117-129. [CrossRef] 